Research Paper

\title{
Eucalyptus short-rotation coppice for solid fuel production
}

\author{
Humberto de Jesus Eufrade Junior ${ }^{\mathrm{a}}$, Gabriela Tami Nakashima ${ }^{\mathrm{b}}$, Fábio Minoru Yamaji ${ }^{\mathrm{b}, *}$, \\ Saulo Philipe Sebastião Guerra ${ }^{\mathrm{a}}$, Adriano Wagner Ballarin ${ }^{\mathrm{a}}$ \\ a Sao Paulo State University - School of Agricultural Sciences (UNESP/FCA), Jose Barbosa Barros St., 1780, Botucatu, Sao Paulo, Brazil \\ b Biomass and Bioenergy Research Group Federal University of São Carlos (UFSCar), Rodovia João Leme dos Santos, km 110, Sorocaba, São Paulo, Brazil
}

\section{A R T I C L E I N F O}

\section{Keywords:}

Briquettes

SRC biomass

Heating value

Mechanical properties

\begin{abstract}
A B S T R A C T
Briquetting provides a homogenous product that has high density, and reduced transport and storage costs in the wood chips supply chain. Few studies evaluated briquettes from eucalypt short-rotation coppice (SRC) managed under tropical conditions and also its energy potential was not clearly defined. The aim of this paper was to assess the quality of briquettes produced from Eucalyptus SRC. The SRC biomass was separated into stem, branches, leaves and mix (produced according to the actual availability in the forest). The physical, chemical and mechanical properties were analyzed. A SEM-EDS (scanning electron microscopy equipped with an energydispersive spectroscopy detector) analysis of ashes from SRC biomass was carried out. Results showed higher energy properties in leaves than for woody fractions, however, its use was limited due to higher content of ash (3.1\%) and a poor mechanical performance. Stem and mix were more suitable for energy purposes, and both treatments reached an energy potential of $14.2 \mathrm{GJ} \mathrm{m}^{-3}$. SEM-EDS analysis showed that the elements Ca, $\mathrm{K}$ and $\mathrm{Mg}$ represented approximately $80 \%$ of the mineral component. It was found that the presence of other regular structures predominantly comprising the elements $\mathrm{Fe}$ and $\mathrm{Al}$ may lead to a serious technical problem. However, briquetting appears as a feasible option to increase added value of forest products from young energetic plantations.
\end{abstract}

\section{Introduction}

Biomass has an important role to play in the production of energy (REN21, 2014), mainly in developing countries (Demirbas et al., 2009; Goldemberg, 1998). The short-rotation coppice (SRC) appears to be a major advancement in alternative renewable energy due to production of high-yielding biomass in a short time (Guerra et al., 2014; Kauter et al., 2003). Harvesting of these dedicated energy crops included all above-ground biomass (stems, branches and leaves) that were chipped by a forage harvester (Guerra et al., 2016; Spinelli et al., 2009).

Whole-tree chips present a high moisture content and low density while presenting some difficulties in transportation, storage and use. The briquetting process presents as an alternative to producing a homogenous and high-density solid product (Grover and Mishra, 1996), improving the biomass quality and reducing supply chain costs (Demirbas, 2010; Kaliyan and Morey, 2009).

Knowledge about the physical and chemical characteristics of briquettes is important to be able to understand the behavior of the burnt fuel, and to consolidate the viability of the biomass supply chain. The briquetting process was consolidated for use in agroindustrial residues
(Felfli et al., 2011). However, few studies evaluated briquettes from SRC managed under tropical conditions, and its energy potential was not clearly defined.

It is known that raw material has a great influence on the quality of briquettes. For forest biomass, the leaves have superior heating value than woody fractions (Cuiping et al., 2004; Pérez et al., 2011), but they have a higher ash content which implies several industrial problems such as encrustation and abrasive wear in metal machines. These aspects also influence its market price (Stolarski et al., 2013).

This paper aims to assess the quality of the briquettes produced from 2 years of eucalyptus plantations managed on SRC. To accomplish this objective, the SRC biomass was separated into stem (wood and bark), branches and leaves, and the physical, chemical and mechanical properties of briquettes were studied.

\section{Materials and methods}

\subsection{Sampling and material preparation}

The sample trees were obtained from an interspecific hybrid of

\footnotetext{
* Corresponding author.

E-mail addresses: hdjejunior@fca.unesp.br (H.d.J. Eufrade Junior), gabrielatn@ufscar.br (G.T. Nakashima), fmyamaji@ufscar.br (F.M. Yamaji), ssguerra@fca.unesp.br (S.P.S. Guerra), awballarin@fca.unesp.br (A.W. Ballarin).
} 
Eucalyptus urophylla $\times$ Eucalyptus grandis (clone C219) plantations that were 2 years old, located at Botucatu City $\left(22^{\circ} 58^{\prime} \mathrm{S}\right.$ and $\left.48^{\circ} 25^{\prime} \mathrm{W}\right)$ Sao Paulo State - Brazil. The local region has an average altitude of $872 \mathrm{~m}$, a mean annual precipitation of about $1428 \mathrm{~mm} \mathrm{year}^{-1}$ and an annual average temperature of $20^{\circ} \mathrm{C}$. The soil of experimental area was a RedYellow Latosol (Oxisol). The crops were managed with a high density of trees per hectare, plots with $2.8 \times 1.5 \mathrm{~m} \mathrm{(2380} \mathrm{trees/ha)}$ and $2.8 \times 0.5 \mathrm{~m}$ (7142 trees/ha).

The equipment used for harvest was New Holland harvester (FR9060 model) fitted with the 130FB header. Twelve medium-sized trees (6-8 cm of diameter breast height and $9-11 \mathrm{~m}$ of mean height) were selected for sampling in the different density planting of Eucalyptus SRC. The trees were separated in the following proportions: stem (wood and bark), branches and leaves. There were collected $8.5 \mathrm{~kg}$ of stem, $1.7 \mathrm{~kg}$ of branches and $1.5 \mathrm{~kg}$ of leaves. After air drying, each portion of the biomass from 12 trees was grinded in a Wiley-type mill and homogenized in a plastic bag.

The material was conditioned to equilibrium in a climate-controlled room under $65 \%$ relative humidity, and $21{ }^{\circ} \mathrm{C}$ (approximately $12 \%$ equilibrium moisture content). The briquettes were produced using a hydraulic press (Marcon, model MPH-30). The briquetting process was performed with $122 \mathrm{MPa}$ of compaction pressure with $30 \mathrm{~s}$ of press time, without the use of temperature and binder. It was used a cylindrical shape metallic support with $35 \mathrm{~mm}$ diameter and $160 \mathrm{~mm}$ height to apply this pressure. It was used approximately $1200 \mathrm{~g}$ of mass for briquetting process ( $20 \mathrm{~g}$ per briquette) with $35 \mathrm{~mm}$ diameter and $20 \mathrm{~mm}$ height.

Four treatments (15 specimens per treatments) were studied considering the different biomasses: 1 . stem; 2 . branches; 3 . leaves and 4. mix (produced according to the real proportions of forest $-72.4 \%$ stem, $14.5 \%$ branches and $13.1 \%$ for leaves). The tests were conducted in the Laboratory of Bioenergy and Lignocellulosic Materials at the Federal University of São Carlos in Sorocaba-SP, Brazil.

\subsection{Physical tests}

The physical characterization was carried out with the following tests: particle size distribution by sifting on 40-200 mesh screens, bulk density of raw materials at dry-air moisture content, briquettes density and expansion (volumetric, axial and radial) at $12 \%$ of moisture content. The briquette density was determined by the ratio of the mass and volume, and the dimensions measurements were obtained within an accuracy of $0.001 \mathrm{~mm}$. The expansions were evaluated at $0,4,12,24$, 48 and $120 \mathrm{~h}$ after production of briquettes. They were maintained in plastic bags throughout this period of the test to avoid humidification.

\subsection{Chemical tests}

The higher heating value (HHV) was obtained by calorimeter, and the lower heating value (LHV) was estimated according to CEN 14918 (2005) using default values found in the Annexure H. Also, the energetic density of briquettes was obtained product-wise between stabilized briquette density and lower heating value. The volatile matter (ASTM E872-82, 2006), ash (ASTM D1102-84, 2007) and fixed carbon (summation of percentage moisture, ash and volatile matter subtracted from 100) were also obtained. All chemical properties were determined in triplicate.

\subsection{Mechanical tests}

The briquettes were mechanically tested in diametrical compression according to NBR 7222 (2011). A computer-controlled electromechanical testing machine EMIC DL30000 (Fig. 1) with $5 \mathrm{kn}$ load cell was used.

Additionally, friability tests were carried out in five samples using a dustproof rotating drum (internal dimensions: $300 \mathrm{~mm} \times 300 \mathrm{~mm}$ $\times 100 \mathrm{~mm}$ ) with $35 \mathrm{rpm}$ during $15 \mathrm{~min}$, resulting in 500 spins. After the procedure, the material was removed from the drum and separated by a sieve with a mesh aperture of $6.3 \mathrm{~mm}$. The material retained on the sieve was weighed. This property is commonly used to evaluate any mechanical action which mainly takes place during transportation, handling and storage of briquettes (Kaliyan and Morey, 2009; Mkini and Bakari, 2015).

\subsection{SEM-EDS analysis of ashes from SRC biomass}

Owing to relevant importance of ash in the industrial process, qualitative and quantitative analyses were realized using a scanning electron microscope (SEM) of Hitachi model TM3000, equipped with an energy-dispersive spectroscopy detector (EDS).

Ten positions, randomly for each sample fraction, were captured with $500 \times$ zoom and $15 \mathrm{kV}$ potential difference in EDS mode operation, and the chemical elements were identified by Quantax 70 software.

\subsection{Statistical methods of analysis}

Basic statistics (central tendency and dispersion) were used in the reporting of properties and SEM-EDS analysis.

The treatments were evaluated by analysis of variance, complemented by a Tukey test (significant at $\mathrm{p}<0.05$ ). It was used the software R (R Development Core Team, 2013).

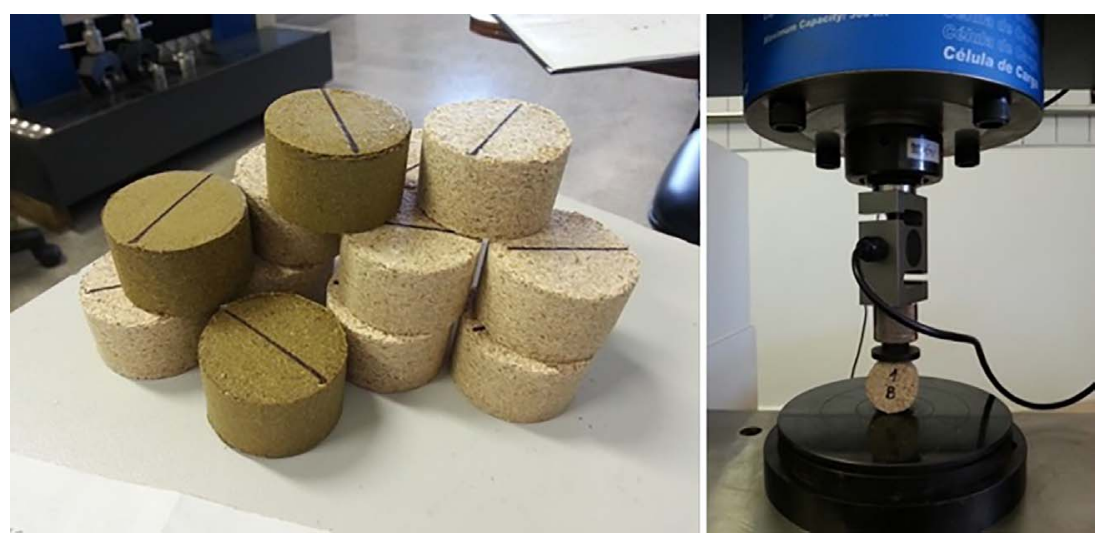

Fig. 1. Briquettes samples and diametrical compression test. 


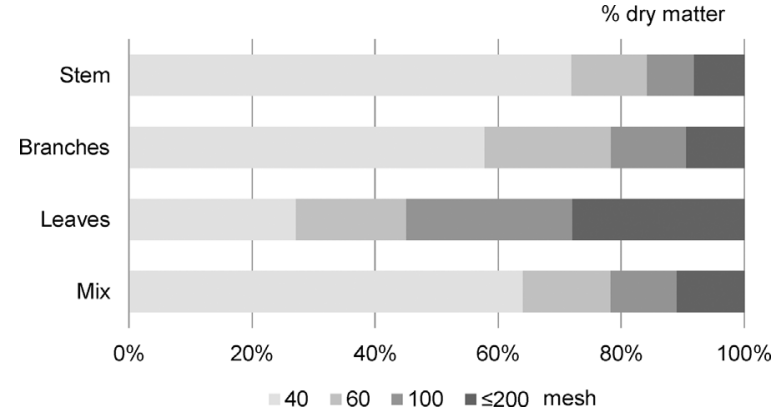

Fig. 2. Particle size distribution before briquetting.

\section{Results and discussion}

\subsection{Properties of briquettes}

The particle size distribution before briquetting has been detailed in Fig. 2.

The stem and mix treatments were mainly characterized by 40 mesh fraction, $72 \%$ and $64 \%$, respectively. The branches and leaves have shown more friability, generating more quantities of fine particles (60 mesh and upper).

Physical and chemical properties of briquettes were statistically different in the treatments (Table 1). The results corroborated with Stolarski et al. (2013) and Srivastava et al. (2014) studying other energy plants.

The results of briquettes' density were similar to those obtained by Ramírez-Gómez et al. (2014) for briquettes of agroforestry residues. Differences among density of fractions can be attributed to particle size distribution of samples. Usually, small particles provide a higher density briquette because of a greater surface area during densification (Tumuluru et al., 2011), however, this trend was not observed and might be attributed to differences in quality of raw material.

The briquettes' densities were almost 7-24 times higher than the bulk density. This densification can reduce the transportation cost which is one of the challenges that seek the economic viability of lignocellulosic products in the supply chain (Papadopoulou et al., 2015).

Higher volatile matter was found in stem biomass, suggesting a more reactive and easily ignitable fuel (Lewandowski and Kicherer, 1997). Already, the leaf biomass obtained a higher fixed carbon that promotes a slow burning compared with other fractions studied.
Energy parameters were superior in briquettes from leaves resulting in higher HHV. It can be explained due to the higher total extractive content of chemical composition of leaves than woody fraction (Senelwa and Sims, 1999). However, they also reached greater ash content which involves several industrial problems such as encrustation and abrasive wear on a metal machine, limiting its use.

The physical, chemical and mechanical results in this study, compared to the older woody species (Brožek et al., 2012; Stolarski et al., 2013) indicates the potential of younger crops to provide a high-quality briquette. Brasil et al. (2015) showed that forest materials can be used for mixing with sugarcane bagasse that is traditionally used for bioenergy in Brazil.

Mechanical performance of stem briquettes was superior to other biomasses, probably due to material content (fibers) and distribution of homogenous particle size (Kaliyan and Morey, 2009). A higher friability performance was found for leaves and branch briquettes, which can produce substantial material losses during transportation and storage in any supply chain (Tumuluru et al., 2011).

Expansion tests were statistically different among fractions (Fig. 3). At $48 \mathrm{~h}$, briquettes reached a stabilized value, and lower data were observed for stem and mix treatments.

It is possible to identify two groups on expansion analysis characterized by woody (stem, branches and mix) and non-woody fractions (leaves) at $12 \%$ of moisture content. Lower expansion values were found for woody briquettes, and it can be explained due to the cellular structure of wood. During densification, the attraction between cellulose tubes can be increased with the presence of moisture content. According to Tumuluru et al. (2011), the densification provided interfacial forces and capillary pressures resulting in a more stable briquette.

Properties studied indicated that stem and mix fractions will be more suitable for energy use, followed by branches and leaves.

\subsection{SEM-EDS perspective of ashes from SRC biomass}

Ash has a relevant impact on industrial activities, and may cause significant damage to metallic equipment during the briquetting process. Therefore, ash content can negate the use of raw material as briquettes.

It was observed, that calcium was the most abundant element present in the ashes of SRC biomass (Table 2). The elements $\mathrm{Ca}, \mathrm{K}$ and $\mathrm{Mg}$, represented approximately $80 \%$ of the mineral phase. Other elements such as $\mathrm{Al}, \mathrm{Mn}, \mathrm{S}, \mathrm{Fe}$ and $\mathrm{Si}$ had a greater variation, although they represented less than $10 \%$ of the total composition.

Table 1

Physical, chemical and mechanical properties of briquettes.

\begin{tabular}{|c|c|c|c|c|c|}
\hline \multirow[t]{2}{*}{ Parameters } & \multirow[t]{2}{*}{ Unit } & \multicolumn{4}{|l|}{ Briquettes } \\
\hline & & Stem & Branches & Leaves & Mix \\
\hline Bulk density ${ }^{a}$ & $\mathrm{~kg} \mathrm{~m}^{-3}$ & $128 \pm 4 a$ & $71 \pm 4 c$ & $36 \pm 2 d$ & $93 \pm 5 b$ \\
\hline Briquette density ${ }^{b}$ & $\mathrm{~kg} \mathrm{~m}^{-3}$ & $924 \pm 12 \mathrm{a}$ & $851 \pm 8 c$ & $866 \pm 19 b$ & $912 \pm 7 a$ \\
\hline Fixed carbon & $\mathrm{wt} \%(\mathrm{DM})$ & $14.4 \pm 0.2 \mathrm{c}$ & $17.3 \pm 0.3 \mathrm{~b}$ & $18.4 \pm 0.2 \mathrm{a}$ & $18.1 \pm 0.5 \mathrm{a}$ \\
\hline Volatile matter & $\mathrm{wt} \%(\mathrm{DM})$ & $84.5 \pm 0.3 \mathrm{a}$ & $81.2 \pm 0.3 \mathrm{~b}$ & $78.5 \pm 0.2 c$ & $80.9 \pm 0.6 \mathrm{~b}$ \\
\hline Ash content & $\mathrm{wt} \%(\mathrm{DM})$ & $1.1 \pm 0.1 \mathrm{c}$ & $1.5 \pm 0.1 \mathrm{~b}$ & $3.1 \pm 0.1 \mathrm{a}$ & $1.0 \pm 0.1 \mathrm{c}$ \\
\hline Higher heating value & $M J k^{-1}$ (DM) & $18.9 \pm 0.1 \mathrm{~b}$ & $19.2 \pm 0.2 \mathrm{~b}$ & $22.0 \pm 0.1 \mathrm{a}$ & $19.1 \pm 0.5 \mathrm{~b}$ \\
\hline Lower heating value & $\mathrm{MJ} \mathrm{kg}^{-1}$ (FM) & $15.4 \pm 0.1 \mathrm{~b}$ & $15.7 \pm 0.2 \mathrm{~b}$ & $18.2 \pm 0.1 \mathrm{a}$ & $15.6 \pm 0.4 b$ \\
\hline Energy density ${ }^{b}$ & $\mathrm{GJ} \mathrm{m}^{-3}$ & $14.2 \pm 0.2 \mathrm{~b}$ & $13.4 \pm 0.1 \mathrm{~d}$ & $15.8 \pm 0.3 \mathrm{a}$ & $14.2 \pm 0.1 \mathrm{~b}$ \\
\hline Abrasion ${ }^{b}$ & $\mathrm{wt} \%(\mathrm{FM})$ & $9.8 \pm 0.9 c$ & $54.8 \pm 4.2 \mathrm{a}$ & $52.2 \pm 4.5 \mathrm{a}$ & $16.8 \pm 2.0 \mathrm{~b}$ \\
\hline Compression strength diametrical ${ }^{b}$ & MPa & $0.91 \pm 0.06 \mathrm{a}$ & $0.25 \pm 0.01 \mathrm{c}$ & $0.22 \pm 0.01 \mathrm{~d}$ & $0.63 \pm 0.03 \mathrm{~b}$ \\
\hline Modulus of elasticity ${ }^{b}$ & $\mathrm{MPa}$ & $30.2 \pm 1.80 \mathrm{a}$ & $10.9 \pm 0.42 \mathrm{c}$ & $7.4 \pm 0.63 \mathrm{~d}$ & $22.7 \pm 2.22 \mathrm{~b}$ \\
\hline
\end{tabular}

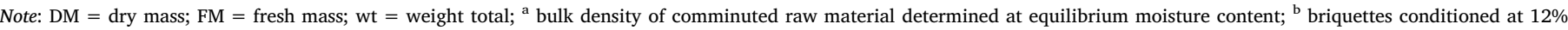
moisture content.

The means that do not differ from each other at the 0.05 significance level by Tukey test are marked with the same letters at same rows. 


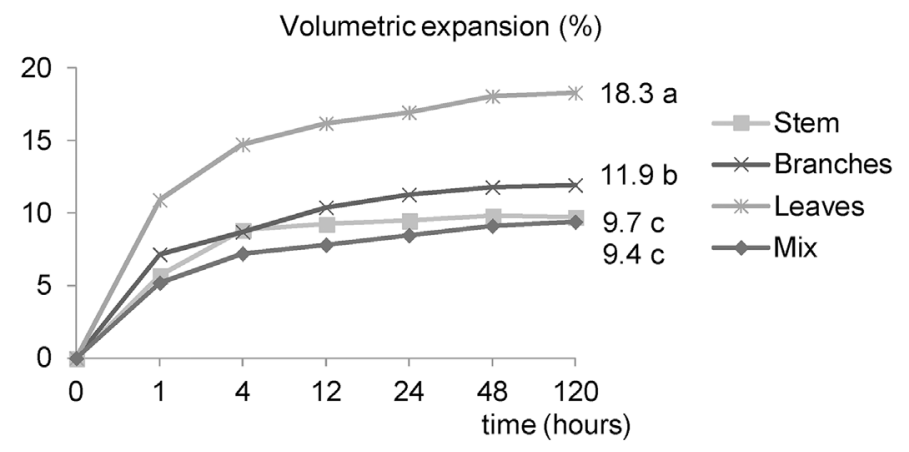

Fig. 3. Expansion tests after briquetting at $12 \%$ of moisture content.

The means that do not differ from each other at the 0.05 significance level by Tukey's test are marked with the same letters.
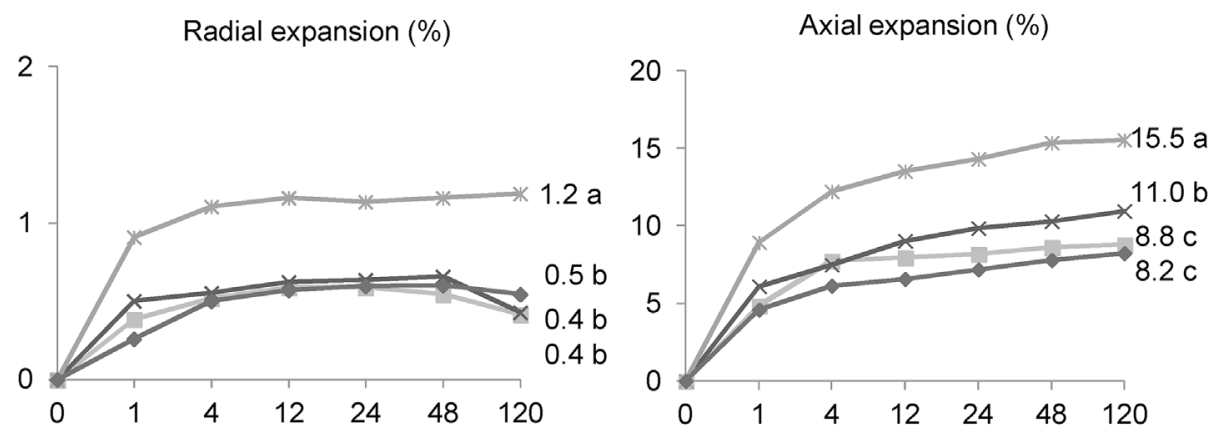

The means that do not differ from each other at the 0.05 significance level by Tukey's test are

marked with the same letters.

Table 2

Chemical elements of ashes from SRC biomass of Eucalyptus grandis $\times E$. urophylla at 2 years old.

\begin{tabular}{llll}
\hline Inorganic elements & Stem wt\% $(\mathrm{DM})$ & Branches wt\% $(\mathrm{DM})$ & Leaves wt\% (DM) \\
\hline $\mathrm{Ca}$ & $49.97 \pm 2.5$ & $55.31 \pm 2.9$ & $36.90 \pm 2.3$ \\
$\mathrm{~K}$ & $22.19 \pm 1.6$ & $21.54 \pm 1.6$ & $21.43 \pm 2.3$ \\
$\mathrm{Mg}$ & $10.27 \pm 1.2$ & $9.50 \pm 1.2$ & $20.24 \pm 1.7$ \\
$\mathrm{Na}$ & $7.32 \pm 0.6$ & $4.57 \pm 0.8$ & $2.20 \pm 0.5$ \\
$\mathrm{Cl}$ & $2.70 \pm 0.9$ & $1.76 \pm 1.0$ & $1.68 \pm 0.3$ \\
$\mathrm{P}$ & $2.29 \pm 0.3$ & $2.79 \pm 0.3$ & $7.24 \pm 0.7$ \\
$\mathrm{Al}$ & $1.68 \pm 0.7$ & $1.32 \pm 0.5$ & $3.16 \pm 1.2$ \\
$\mathrm{Mn}$ & $1.34 \pm 0.6$ & $1.22 \pm 0.4$ & $1.08 \pm 0.2$ \\
$\mathrm{~S}$ & $0.79 \pm 0.3$ & $0.56 \pm 0.3$ & $1.01 \pm 0.3$ \\
$\mathrm{Fe}$ & $0.91 \pm 0.5$ & $0.91 \pm 0.7$ & $1.80 \pm 0.5$ \\
$\mathrm{Si}$ & $0.54 \pm 0.2$ & $0.61 \pm 0.3$ & $3.15 \pm 0.6$ \\
\hline
\end{tabular}

It was established, that the following sequence of chemical elements for stem fraction: $\mathrm{Ca}>\mathrm{K}>\mathrm{Mg}>\mathrm{Na}>\mathrm{Cl}=\mathrm{P}>\mathrm{Al}=\mathrm{Mn}$ $>\mathrm{Fe}=\mathrm{S}>\mathrm{Si}$; for branches fraction: $\mathrm{Ca}>\mathrm{K}>\mathrm{Mg}>\mathrm{Na}$ $>\mathrm{P}>\mathrm{Cl}=\mathrm{Al}=\mathrm{Mn}>\mathrm{Fe}=\mathrm{Si}=\mathrm{S} ;$ and leaves fraction: $\mathrm{Ca}>\mathrm{K}=\mathrm{Mg}>\mathrm{P}>\mathrm{Si}=\mathrm{Al}>\mathrm{Na}>\mathrm{Cl}=\mathrm{Fe}>\mathrm{Mn}=\mathrm{S}$.

Silica has a significant role to play in the damage of industrial equipment in the briquetting process. This damage is occasioned due to the formation of silicates, as shown in Fig. 4.

Although, it was found that there were small amounts of silica in the ashes of SRC biomass. This result was based on clean samples and, if used at commercial scale, soil particles loaded during harvesting must be taken into consideration.

The images also showed the presence of other regular structures, predominantly of $\mathrm{Fe}$ and $\mathrm{Al}$ elements (Fig. 5). In the combustion of briquettes, these compounds could lead to a serious technical problem for boilers. Generally, alkali metals are the main causes for the production of slag and encrustations (Cuiping et al., 2004).

The results showed that there is a potential to use the whole tree of SRC biomass. During the cycle, the eucalyptus leaves fall naturally and are deposited in the soil and its retention in soil has an important contribution to organic matter, thus maintaining it for further rotations (Achat et al., 2015).

\section{Conclusions}

Briquetting is a feasible option for solving low density issue of biomass from SRC.

Physical, chemical and mechanical properties indicated that the stem and mix briquettes (whole tree) were better options for energy use. Higher ash content and poor mechanical performances were negative aspects for use of leaf and branch biomass for briquetting.

It was found that the presence of silica and other structures (predominately composed of $\mathrm{Al}$ and $\mathrm{Fe}$ ) in the ashes of briquettes were likely to cause serious drawbacks to the industrial process.

\section{Acknowledgements}

The authors would like to thank the Coordination for the Improvement of Higher Education Personnel (CAPES), the Laboratory of Agroforest Biomass Bioenergy (LABB) - Institute of Bioenergy Research (IPBEN) and the School of Agricultural Sciences (FCA) - Sao Paulo State University (UNESP). 


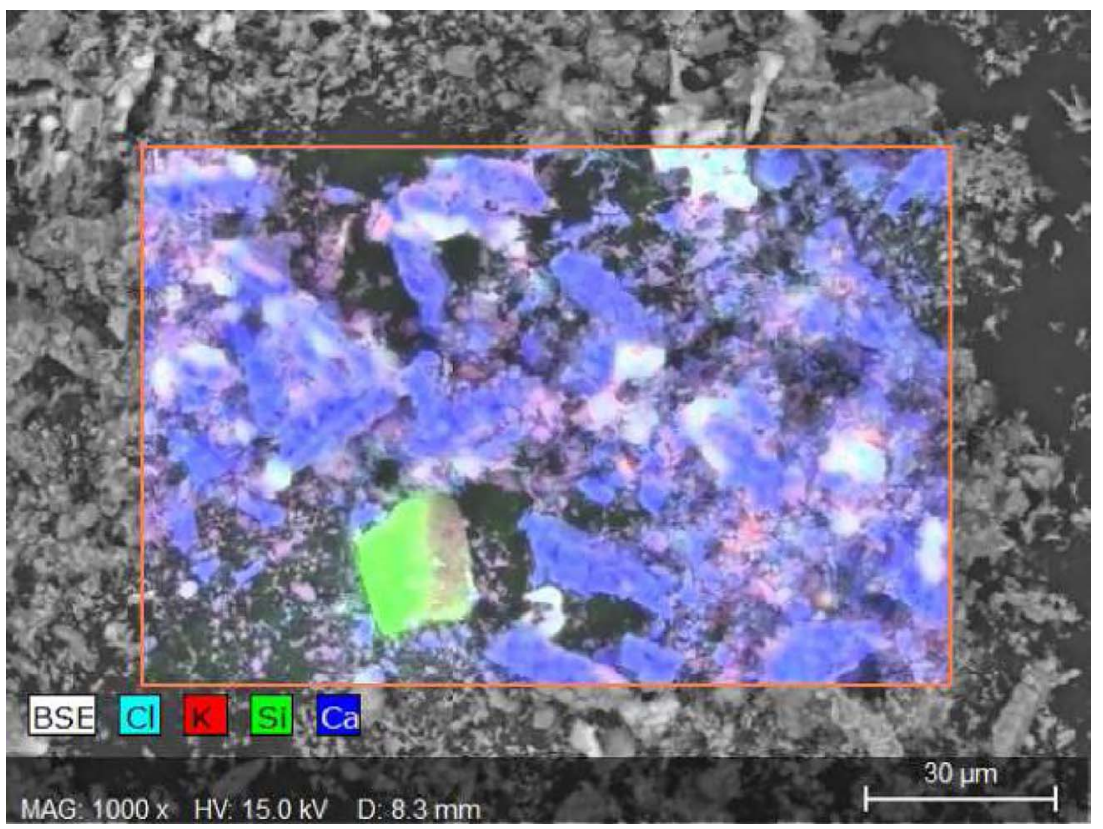

Fig. 4. Silicate highlighted (green) in the ashes of stem fractions. (For interpretation of the references to colour in this figure legend, the reader is referred to the web version of this article.
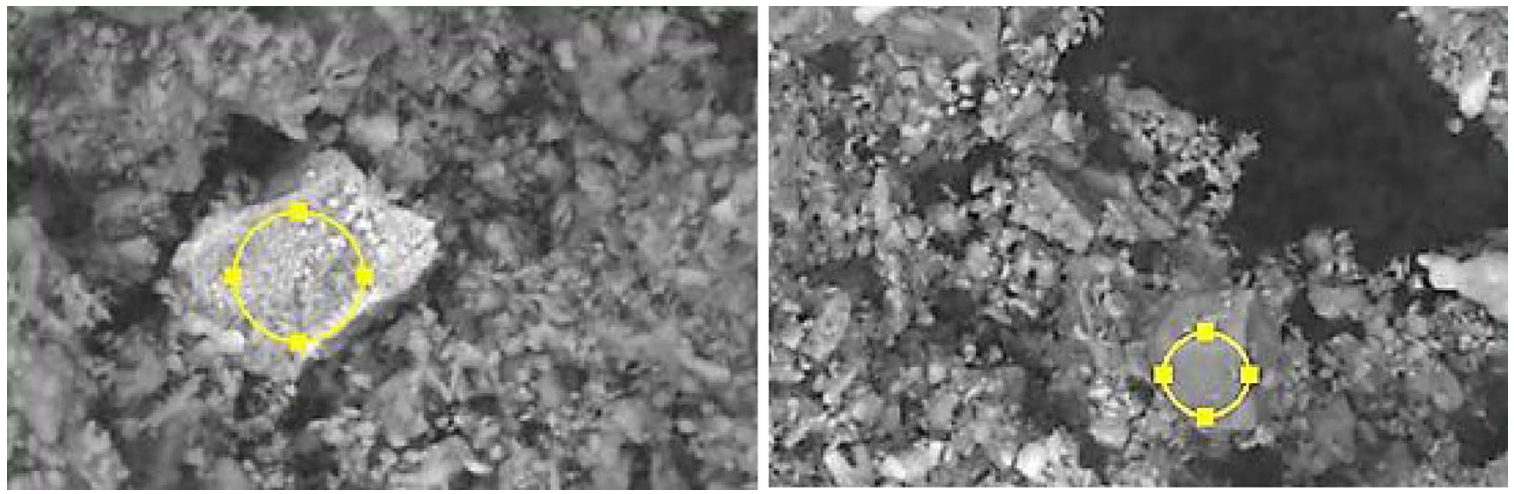

Fig. 5. Regular form structures (predominantly of Fe and Al elements) presented in the ashes of SRC biomass captured by scanning electron microscopy (1500 $\times$ zoom).

\section{References}

DASTM D1102-84, 2007. Standard Test Methods for Ash in Wood. West Conshohocken, PA.

ASTM E872-82, 2006. Standard Test Methods for Volatile Matter in the Analysis of Particulate Wood. West Conshohocken, PA.

Achat, D.L., Deleuze, C., Landmann, G., Pousse, N., Ranger, J., Augusto, L., 2015. Quantifying consequences of removing harvesting residues on forest soils and tree growth - a meta-analysis. For. Ecol. Manage. 348, 124-141.

Brasil, D.S., Martins, M.P., Nakashima, G.T., Yamaji, F.M., 2015. Use of sugarcane bagasse and candeia waste for solid biofuels production. Floresta 45 (1), 185-192.

Brožek, M., Nováková, A., Kolářová, M., 2012. Quality evaluation of briquettes made from wood waste. Res. Agr. Eng. 58, 30-35.

CEN 14918, 2005, 2005. Solid Biofuels - Method for the Determination of Calorific Value. British Standards Institution, London.

Cuiping, L., Chuangzhi, W., Yanyongjie, Huang, H., 2004. Chemical elemental characteristics of biomass fuels in China. Biomass Bioenergy 27, 119-130.

Demirbas, M.F., Balat, M., Balat, H., 2009. Potential contribution of biomass to the sustainable energy development. Energ. Conver. Manage. 50, 1746-1760.

Demirbas, A., 2010. Charpter 2: Fuels from Biomass. In: Demirbas, A. (Ed.), Biorefineries: for biomass upgrading facilities. Springer, London, pp. 33-73.

Felfli, F.F., et al., 2011. Biomass briquetting and its perspectives in Brazil. Biomass Bioenergy 35, 236-242.

Goldemberg, J., 1998. Energia e desenvolvimento (in portuguese). Estudos Avançados 12, $7-15$.

Grover, P.D., Mishra, S.K., 1996. Biomass Briquetting: Technology and Practices. RWEDP, FAO, Bangkok.

Guerra, S.P.S., Garcia, E.A., Lanças, K.P., Rezende, M.A., Spinelli, R., 2014. Heating value of eucalypt wood grown on SRC for energy production. Fuel 137, 360-363.

Guerra, S.P.S., Oguri, G., Spinelli, R., 2016. Harvesting eucalyptus energy plantations in Brazil with a modified New Holland forage harvester. Biomass Bioenergy 86, 21-27.

Kaliyan, N., Morey, R.V., 2009. Factors affecting strength and durability of densified biomass products. Biomass Bioenergy 33, 337-359.

Kauter, D., Lewandowski, I., Claupein, W., 2003. Quantity and quality of harvestable biomass from Populus short rotation coppice for solid fuel use - a review of the physiological basis and management influences. Biomass Bioenergy 24, 411-427.

Lewandowski, I., Kicherer, A., 1997. Combustion quality of biomass: practical relevance and experiments to modify the biomass quality of Miscanthus x giganteus. Eur. J. Agron. 6, 163-177.

Mkini, R.I., Bakari, Z., 2015. Effect of moisture content on combustion and friability characteristics of biomass waste briquettes made by small scale producers in Tanzania. Int. J. Eng. Res. Rev. 3, 66-72.

NBR 7222, 2011. Concrete and Mortar -determination of the Tension Strength by Diametrical Compression of Cylindrical Test Specimens (in Portuguese). ABNT standard, Rio de Janeiro.

Pérez, S., et al., 2011. Energetic density of different forest species of energy crops in Cantabria (Spain). Biomass Bioenergy 35, 4657-4664.

Papadopoulou, E., Bikiarisb, D., Chrysafis, K., Wladyka-Przybylak, M., Wesolek, D. Mankowski, J., Kolodziej, J., Baraniecki, P., Bujnowicz, K., Gronberg, 2015. Valueadded industrial products from bast fiber crops. Ind. Crop. Prod. 68, 116-125.

R. Development Core, 2013. R: A Language and Environment for Statistical Computing. R Foundation for Statistical Computing, Vienna, pp. 2013.

Renewables 2014 Global Status Report. Renewable Energy Policy Network for the 21 St Century. REN21 Secretariat, Paris, pp. EN21.

Ramírez-Gómez, Á., Gallego, E., Fuentes, J.M., González-Montellano, C., Ayuga, F., 2014 Values for particle-scale properties of biomass briquettes made from agroforestry residues. Particuology 12, 100-106.

Senelwa, K., Sims, R.E.H., 1999. Fuel characteristics of short rotation forest biomass. Biomass Bioenergy 17, 127-140.

Spinelli, R., Ward, S., Owende, P., 2009. A harvest and transport cost model for Eucalyptus spp. fast-growing short rotation plantations. Biomass Bioenergy 33, 1265-1270.

Srivastava, N.S.L., Narnaware, S.L., Makwana, J.P., Singh, S.N., Vahora, S., 2014. Investigating the energy use of vegetable market waste by briquetting. Renew. Energy. 68, 270-275.

Stolarski, M.J., et al., 2013. Comparison of quality and production cost of briquettes made from agricultural and forest origin biomass. Renew. Energy 57, 20-26.

Tumuluru, J.S., Wright, C.T., Hess, J.R., Kenney, K.L., 2011. A review of biomass densification systems to develop uniform feedstock commodities for bioenergy application. Biofuels, Bioprod Bioref. 5, 683-707. 